\title{
GREEN LOGISTICS APPLICATION TO REDUCE OPERATING COSTS FOR VIETNAM LOGISTICS ENTERPRISES
}

\author{
Huynh Dang Khoa ${ }^{1}$, Tran Thi Bich Nhung ${ }^{2}$ \\ ${ }^{1}$ Foreign Trade University Hochiminh city campus, 15 D5 Street 25 Ward Binh Thanh District, \\ HochiminhCity, 084, Vietnam, huynhdangkhoa.cs2@ftu.edu.vn, (028.35127258) \\ ${ }^{2}$ Foreign Trade University Hochiminh city campus, 15 D5 Street 25 Ward Binh Thanh District, \\ HochiminhCity, 084, Vietnam, tranthibichnhung.cs2@ftu.edu.vn, (0938028655)
}

\begin{abstract}
Green logistics is one of the current trends that logistics enterprises in countries have been applying for their logistics activities to achieve economic efficiency issues, but still ensure environmental friendliness and achieve social responsibility. In this article, the author wants to introduce readers the trend of green logistics applications in reducing operating costs of logistics enterprises; illustrated by typical successful situations of businesses around the world. Since then, propose some recommendations for Vietnam logistics enterprises in applying green logistics into enterprises to have the opportunity to reduce operating costs, integrate well with the world, and create competitive advantage for businesses in the same industry.
\end{abstract}

Keywords: Green logistics, operating costs, sustainable logistics.

\section{JEL Classification}

C52

DOI: https://doi.org/10.14311/bit.2020.02.01

Editorial information: journal Business \& IT, ISSN 2570-7434, CreativeCommons license (c) (1) published by CTU in Prague, 2020, http://bit.fsv.cvut.cz/

\section{Introduction}

Green Economy is one of the current trends of the world in order to develop the economy in a sustainable way while creating value but still ensuring the development of human life and social responsibility and environmentally friendly. Many countries in the world have been applying "greening" into the development of their economic industries, and Logistics is one of the sectors that have a great impact on society is not out of trend. The challenge is still to develop the logistics industry to ensure the criteria of economic efficiency but still have to meet well social and environmental issues. Can green logistics trends solve this challenge? Will green logistics bring challenges to logistics enterprises or help them optimize business issues and develop sustainably? What lesson for Vietnamese logistics enterprises in green logistics application for sustainable development? 


\section{Review on journal writing}

\section{Green Logistics}

Typically, logistics is seen as the actions of which the objective is to minimize costs and maximize profits. The term was used mostly in purely business areas exhibiting companies and in financial reports. But, for many years, the term logistics was used in conjunction with the "green" by creating "Green Logistics" - the term containing costs, yet did not appear on financial reports and on the environment and society. The term "green logistics" is defined as supply chain management practices and strategies that reduce the environmental and energy footprint of freight distribution, which focuses on material handling, waste management, packaging and transport (Rodrigue et al., 2012).

Green logistics consists of all activities related to the eco-efficient management of the forward and reverse flows of products and information between the point of origin and the point of consumption whose purpose is to meet or exceed customer demand (Mesjasz-Lech, 2011).

Lee and Klassen (2008) describe green logistics as Green Supply Chain Management that can be defined as an organizations activity taking into account environmental issues and integrating it into supply chain management in order to change the environmental performance of suppliers and customers.

Green logistics activities include measuring the environmental impact of different distribution strategies, reducing the energy usage in logistics activities, reducing waste and managing its treatment (Sibihi and Eglese, 2009).

From the sustainable development point of view, green logistics can be defined as, "producing and distributing goods in a sustainable way, taking account of environmental and social factors" (Sibihi and Eglese, 2009). This broad definition of green logistics is consistent with the definition of sustainable development and the definition of corporate social responsibility (Lyon \& Maxwell, 2008).

Three aspects of sustainable development can be applied to green logistics (Figure 1).

Figure 1: Green Logistic is a factor of sustainable development

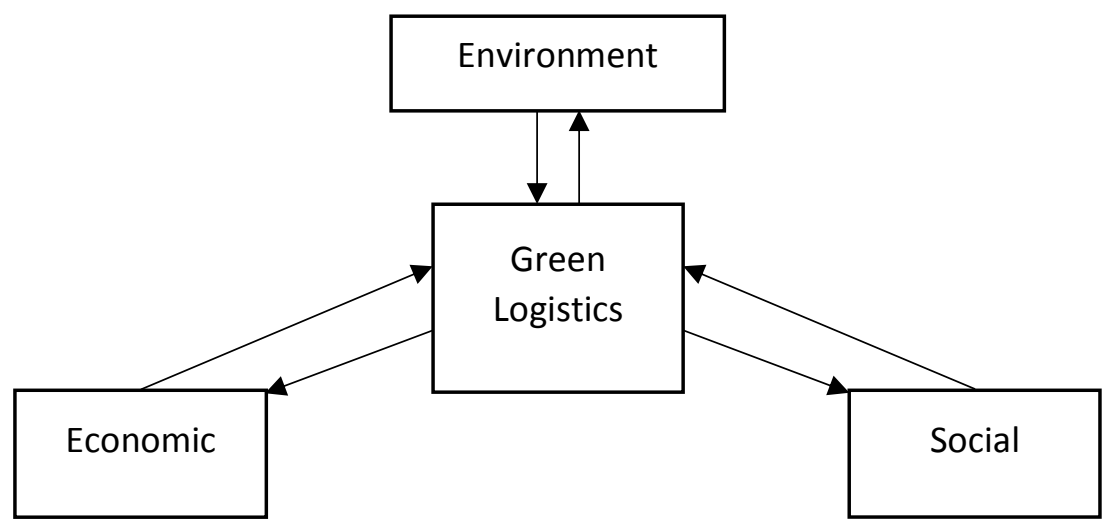

Source: Seroka-Stolka, O., 2014

As mentioned in the definitions of green logistics before, in the past, companies coordinated their logistics activities comprising freight transport, warehousing, packaging, materials handling and data collection and management to meet customer requirements at minimum cost which just refers to the monetary terms (Nowakowska-Grunt, 2008). Now, the environment has become a 
concern. It is treated as a factor of the cost. Some companies have already taken external costs of logistics associated especially with the environmental issues such as climate change, pollution and noise into account. Green logistics is therefore defined as efforts to examine ways of reducing these externalities and achieving a more sustainable balance between environmental, economic and social objectives, (see Figure 1). All efforts in the "green" logistics area are therefore focused on contributing towards, and ensuring, sustainability (Hans, 2011).

Geroliminis and Dagazo (2008) in their study have mentioned the steps of green logistics application in urban areas, and many different areas that have an impact on the environment have been divided into three main groups as follows:

- Activities of green logistics: transportation, distribution centers; packaging; waste management; logistics data collection and processing process.

- Institutions: Policies on green logistics for motor vehicles; policies on production processes in enterprises.

- Impacts: Economics; society; human; environment

\section{Impact of implementing green logistics to reduce operating costs of logistics enterprises}

Pesch, M.J., Murphy, R.T. and Ahmad, S., (2012) have argued that in recent years due to increased awareness of environmental issues, consumers not only demand environmentally friendly products and services but also expect companies to operate their businesses to pay attention to environmental impacts. Companies are meeting this demand by assessing ways to adopt the best methods of environmental sustainability. More and more companies are bringing environmental performance, "green" values to their core business goals, making sustainable environmental and social plans, and requiring their suppliers to incorporate "green" methods in their operations.

Many companies want to make environmentally friendly changes to their business practices, but the high cost of these proposals has made them difficult to make decisions. This leads to the implementation of sustainable business that will be particularly difficult for small businesses struggling to survive in a competitive market. However, most of these companies cannot ignore the opportunities and competition requirements of today's sustainable business methods. High energy costs, industry trends and direct pressure from customers are the forces that drive company leaders to think deeply and creatively about sustainability in accordance with their future strategy. This is especially true in the shipping/ logistics industry. In the United States, transport accounted for about $28 \%$ of energy consumption and $33 \%$ of carbon dioxide emissions in 2007.

For this reason, focusing on the supply chain of businesses, especially warehouse management and distribution networks can contribute significant advances in sustainability. This view is shared by many experts and business leaders, including Brain Walker, CEO of furniture maker Herman Miller, who once stated, "your business is only available "green" when your supply chain is "green".

Warehouses is the key players in the supply chain network of businesses and industries. According to industry statistics in 2009, there are 5 billion square feet of warehouse space in the United States - 16 square feet for each person in the country. The total cost of annual warehousing services in the United States is about 122 billion dollars (or $\$ 407$ per person). 
Warehouses have a significant impact on costs, efficiency and environmental impacts of supply chain systems. They occupy large areas of land that turn soil surfaces absorb water into roofs and waterproof asphalt. In addition, they often feature arces of surrounding green space that require mowing, watering, fertilizing, using herbicides and pesticides. Warehouses are also places that use a lot of energy for lighting, heating, and sometimes cooling hundreds or even thousands of square feet of space. Warehouses are often the main contributors to the "urban heat island" effect where buildings and parking lots absorb and retain heat from the sun and increase the overall average temperature of the surrounding urban areas.

\section{Research methodology}

The research was conducted by qualitative methods - case study research. To carry out this research, the author used methods of searching information from scientific articles of prestigious scholars around the world, famous situations of successful application of green logistics on reducing operating costs of logistics enterprises in the world. Since then, the author combined with the current situation of Vietnam's logistics industry, and on that basis, proposed recommendations to apply green logistics to reduce operating costs of Vietnamese logistics enterprises.

\section{Case Studies}

\section{Murphy Logistics: Sustainable logistics}

Pesch, M.J., Murphy, R.T. and Ahmad, S., (2012) have built the following case of Murphy warehousing company:

Murphy Warehouse (MWC) is one of the largest logistics companies in Upper Midwestern United States. It is a private family-owned company founded in 1904. Richard Murphy Jr. represents the fourth generation of the company. MWC has operated 12 warehouses in the Twin Cities metropolitan area with a total area of 2.6 million square feet, including four warehouses owned by Murphy with a total area of 1.1 million square feet. The supply chain logistics services provided by the company include:

- Product distribution

- Transportation management and consolidation

- Warehouse storage

- Rail transportation

- Fullfillment of orders

- Returns management

- Value added customer service

- Pick and pack

MWC controls 31,000 SKUs - storage units, has 125,000 trucks for loading and unloading, 6000 cars per year. Today, MWC's staff includes 200 employees who provide customers with outstanding logistics solutions, no matter how complex the work is.

In 1987, when the US federal government introduced a Clean Water Act that imposed local governments on the management of storm water quality to ensure protection against contaminants. From rainwater flowing into rivers and lakes. However, the federal government did not fund the local government to solve this problem, and was forced to pay for these clean water treatment, the Minneapolis government collected the water treatment fee of those consumers, 
property owners and even residential areas. Warehouse 701 is the oldest warehouse in MWC's four warehouses. The buildings were originally built in this area in 1904, with several expansions for decades leading to the present 550.000 square foot facility. Ninety-five percent of this 22-acre area, including a roof or impervious pavement, created a large amount of rainwater. Most of this water flows into Minneapolis's storm sewer system, costing tens of thousands of dollars of MWC every year.

Murphy researched and found an engineer who could design and construct a storm water system for Warehouse 701 at a cost of $\$ 580,000$. It will include a large basin, three areas to absorb rainwater, and repair the roof of buildings to manage the sudden rise of rainwater.

The challenge for Murphy is to determine whether the high cost of the project and the longer payback period can be effective. Certainly, the project will largely help the company not pay quarterly storm sewer bills from Minneapolis City. And processing storm water on-site also was the environmentally responsible action.

In the mid-1990s, Richard Murphy took a closer look at MWC's operations and saw a number of opportunities to capture the cost and performance advantages of his company by investing in sustainable projects strong.

\section{The transformation of Lawn into Prairie}

The first project Murphy made was that he had turned the total area of lawn over 10.19 acres with the traditional Kentucky blue grass in growing, maintaining and caring into prairie flower and grasses. The annual cost of maintaining 10.19 acres is illustrated in Table 1 . He contacted Prairie Restorations, a company specializing in planting and maintaining indigenous grasslands to replace 6 acres. He lands the lawn into native grassland, with a planting cost of $\$ 6,575$ per acre.

Table 1: The annual costs of maintaining 10.19 acres of total lawn area

\begin{tabular}{|l|l|}
\hline & Annual Costs \\
\hline Mowing & $\$ 29.220$ \\
\hline Watering & $\$ 20.988$ \\
\hline Fertilizing & $\$ 2.444$ \\
\hline Total & $\$ 52.652$ \\
\hline Cost per acre & $\$ 5.167$ \\
\hline
\end{tabular}

Source: Pesch, M.J., Murphy, R.T. and Ahmad, S., 2012

The prairie landscape provides immediate cost savings for MWC. Indigenous grasslands have low maintenance costs, only need attention occasionally, including regulatory burning, controlling exotic species, maintaining wildflowers and not needing to cut grass. The annual cost of maintaining grassland areas of MWC is \$ 707 - less than 14 percent of the cost of mowing, watering and fertilizing Kentucky green grass.

In addition to this prairie project and two other, MWC has gained many benefits by planting 732 trees in warehouse areas. The plants helped reduce the "urban heat island" effect by cooling the air through photosynthesis and covering the surrounding soil surfaces. These trees also provide thermal buffering between warehouse operations, adjacent commercial properties and residential areas. 


\section{Dock Blankets}

Another sustainable practice at MWC was the application of dock blankets to cover steel dock plates that extend from the outdoor wall to ten feet inside the loading areas in the warehouse. The steel plates cause significant heat loss by two factors: (1) transfer winter cold outdoor temperatures directly to the storage and (2) because the steel plates cannot hold each other against penetration of the wind. Murphy thought these plates as "ice cubes" inside the building, chilling space like ice in a drink.

To combat the problem of heat loss, the operation team ordered electrical insulation covers used in the furniture industry to use when moving furniture. The covers are the right size for the dock plates in the warehouse, and during winter the employees cover the dock plates whenever they are not used, even within ten minutes. Immediately, the heating cost of MWC decreased by $10 \%$ and the temperature around the loading and unloading area increased by ten degrees or more, a result that satisfied the workers there. The relatively small investment in the cover was returned within a few days by the employee comfort and within a few months of saving heating bills.

\section{Lighting}

Lighting is an area where significant improvements in energy efficiency over the past fifteen years have made MWC invest heavily in upgrading lighting to acquire new savings. For example, recently, MWC has replaced lighting systems for only five years because new "T-8" devices reduce lighting costs by nearly $20 \%$ compared to older devices. (This five-year system is considered "advanced" at the time it is installed.) The payback period on new T-8 lighting systems is only 1416 months, which reinforces trust. Murphy always update new energy-saving technologies. Another important measure taken by MWC to improve lighting performance is to paint the white warehouse ceiling so the light is reflected down from the ceiling instead of being absorbed. In the past, warehouses were usually built with dark gray ceilings.

\section{Sustainable future plans}

Richard Murphy planned to move forward to ensure sustainability is an important part of MWC's competitiveness and profitability. From his extensive involvement in the business community and his conversations with customers, he knows that sustainability has become a core criterion in acquiring a new business. Many customers looking for partnerships with logistics service providers can complement their own green initiatives and sustainability has become closely linked to economic performance criteria."

\section{LEED certification}

Murphy is currently working with a consultant to prepare and apply for LEED Gold certification for MWC. There are four LEED certification levels: Certification, Silver, Gold and Platinum. While many companies seek LEED certification, only $13 \%$ of these companies complete this process. "Gold" is the second highest level of LEED certification and a clear achievement that MWC can use to attract new customers.

\section{Energy Star certification}

As part of the LEED certification process, it was discovered that MWC's facilities also achieved EPA's Energy Star Certification, with scores in the 99th order: "Most effective." According to Wikipedia, the Environment Star's Energy Star program has developed an energy efficiency rating 
system for several types of commercial construction, agencies and production facilities. These ratings, on a scale of 1 to 100, provide the means to measure the energy efficiency of specific industrial buildings and plants compared to the energy efficiency of similar facilities. Ratings are used by construction and energy managers to assess the energy performance of existing buildings and industrial plants. Evaluation systems are also used by EPA to determine if a building or factory is eligible for Energy Star recognition."

\section{ISO 14000 certification}

Another green initiative of MWC is to prepare and submit ISO 14001 certification as an ongoing person. According to the International Organization for Standardization (ISO), the main objective of ISO 14000 is "to promote more effective and efficient environmental management in organizations and to provide useful and useful tools - ones that are cost-effective, system platform, flexibility and reflect the best organizational practices available for gathering, interpreting and communicating environmentally relevant information". The goal of ISO 14000 certification is to improve environmental performance.

\section{New green initiatives}

Richard Murphy was confident that the sustainable measures his company had taken so far were sufficient to achieve LEED and ISO 14001 certification. But he also knew that there were other new green initiatives he might consider adopting. Richard Murphy Jr. was considering installing solar cell technology on the roofs of warehouses at MWC, as well as possibilities wind turbines that can be installed on the roof.

\section{DHL - Green Logistics}

According to Cosimato, S. and Troisi, O., (2015) on DHL's logistics case study, since 2009, DHL has focused on social responsibility and sustainability and they has develop the following programs: PPGoGreen, dedicated to environmental protection; PPGoHelp, dedicated to disaster management; PPGoTeach, dedicated to the expansion of educational activities in the world. In terms of sustainability, DHL believes that sustainable and environmentally friendly services can contribute to improving long-term competitiveness. Therefore, sustainability will also have a positive impact on new customer attraction and retention of existing customers. The most important sustainable actions involve optimizing transportation routes, using environmentally friendly motor vehicles and replacing energy efficient logistics operations. DHL provides a large number of green-oriented products and services to reduce $\mathrm{CO} 2$, and reduce greenhouse gas emissions. In summary, the company believes that environmental protection and business success are not only compatible, but also closely related.

One of DHL's best practices is "greening outbound logistics functions". Specifically of this action is the company has developed all kinds of packaging in order to pack the goods can be recycled $100 \%$, based on low-impact materials to the environment in all shapes and sizes. DHL has also used QR codes to paste on its packages, there is information about the package in each QR code (tracking, shipping costs, packages in which country, information DHL office, ...) to provide the carrier and consumer all the information they need about the shipping process. At the same time, the company has also developed multi-purpose containers that can be recovered - "multipurpose returnable containers - MRC" can reduce the environmental impact during the transportation of precision equipment by reusing containers many times. DHL has also introduced a new product for 
the transport of bulk non-toxic liquids, designed for the chemical and beverage industry in accordance with ISO regulations for containers.

The company has also partnered with Renault Trucks and Grand Lyon in testing an experimental vehicle-friendly environment in order to promote a campaign to reduce the consumption market of their fuel cargo, estimated if this technology is put to use, will fall more than 1 million liters of gasoline in 1 month, and apply this to smart freight forwarding in European urban spaces.

From improvements trending green logistics DHL led to DHL's competitiveness has improved a lot, especially in terms of economic efficiency. In 2013, DHL became the leading company in the logistics market in particular 85 countries with total sales up to 13 billion euros (financial statements of DHL - www.dhl.com) and market shares of DHL about $42.3 \%$ during the year.

From the situation of Murphy Warehouse Company and DHL Company, we can see more clearly a trend that has been emerging in the logistics industry. Large logistics companies around the world are also gradually replacing their traditional logistics processes in the direction of "greening" to both ensuring economic benefits and saving the gradual material resources and reducing the operating costs of its businesses in a positive way and managing logistics activities in a scientific, intelligent and more accurate way. These are the economic benefits of green logistics. In the environment and society aspect, as business development towards green logistics means that are performing their responsibilities to the environment, to the community - those existing and future customers. Summing up all these aspects together will lead to sustainable logistics.

\section{Recommendations for Vietnam Logistics Companies}

\section{General characteristics of Vietnamese logistics companies}

According to the information provided in the 2017 Logistics Report, announced by the Vietnam Ministry of Industry and Trade when assessing the situation of Vietnam logistics enterprises in 2017 as follows: "Vietnam logistics enterprises is relatively young but rapidly growing, largely derived from the operational point of traditional transportation and warehousing ... are developing integrated services have high levels of high added value. However, at present Vietnam enterprises only represent a small market share. Capacity among businesses uneven, lack of professionalism, logistics activities are fragmented, lack of connection should not increase convince carriers outsource logistics services. "

According to the logistics performance assessment report (LPI) published by the World Bank every 2 years, in 2016, Vietnam's LPI index has decreased by 16 grades (still ranked top 4 in the ASEAN region) falling to the position of $64 / 160$ countries in the rankings. The main cause of the downgrade is due to factors affecting the logistics industry are falling, in which a very important point is the operating costs of logistics services at a high level and quality of service delivery to low while the market increasingly fierce competition. According to the World Bank, the cost of Vietnam logistics enterprises twice with developing country and higher than the industry average of $14 \%$ globally.

\section{Recommendations}

Based on the shortcomings of operating costs of Vietnam logistics enterprises combined with the benefits of green logistics that bring about economic, environmental and social efficiency, along with successful examples in applying use green logistics into their businesses: Murphy warehouse company; DHL Corporation, the author proposes a number of recommendations for the Vietnam 
logistics enterprises to apply green logistics in your business in order to reduce operating costs, competitive advantage and positive impact on the environment and society.

First, the application of environmentally friendly materials in replacing traditional materials in warehouses. The majority of warehouses in Vietnam are mainly built in the traditional metal materials: iron, steel, cement, etc. These traditional materials must be gradually replaced by other materials to protect the environment and economy. For example, in the following case, Vietnam is a tropical country, with a high number of sunshine hours in the year, enterprises can use solar panels installed on the roof to both utilize the power to operate the warehouse and reduce the cost of electricity consumption.

Second, logistics enterprises should pay attention to long-term investments, rather than shortterm ones. Investment in green logistics is an investment that has long-term benefits. This means that, in the short term, green logistics application enterprises must accept the problem of increasing costs for technology, transportation investment, warehouse conversion and not gaining profits in the short term. . Therefore, if enterprises invest, they must consider whether this issue is suitable for the company's objectives.

Third, businesses should focus on applying technologies to their main logistics operations. Application in logistics; management of warehouses and transportation; human management; goods management; stakeholder management. This application is intended to be better accessible; meeting the requirements of E-commerce enterprises can both focus on detecting, warning early risks, and early detection in at specific stages during logistics process, both managing warehouses in a smart way and limiting to the maximum the unnecessary activities.

Fourth, the main investment for shipping quality. Transporting is the lifeline of logistics process, enterprises should focus on investment in transport in the direction of modern and fuel efficient, to have the ability to turnaround faster, minimizing failures due to poor equipment quality, combined with the application of technology in equipment management.

Fifth, establishing a "green" relationship with upstream and downstream partners of the logistics process. This will help businesses get a spread of "green" for their stakeholders, and this is also an opportunity to clearly demonstrate the competitive advantage of "Green logistics enterprises" than the same industry does not apply green logistics. In addition, when such partners are established, there will be cost sharing for stakeholders when they agree to apply green logistics, resulting in reduced operating costs.

Sixth, enterprises must apply "green" criteria such as LEED, ISO, ... in their own activities. These are the "measure" general green businesses worldwide, and through the application of these criteria, the Vietnam enterprises can gradually improve better their activities, integration, and the easy acceptance of the partners involved.

\section{Conclusion}

The research would like to bring to our readers the basic knowledge about the trend of green logistics in the world, and mention the problems about operating costs that Vietnam logistics enterprises are facing. The benefits that green logistics offers, as well as this trend is happening in the world market is undeniable. If Vietnam logistics enterprises want to increase the competitive advantage in the long term, this is an significant legal considerations.

Through research, the author proposes a number of recommendations for the logistics enterprises in Vietnam in the application of green logistics in the enterprise to create a reduction 
in operating costs, in order to create a competitive advantage and achieve long-term sustainable logistics.

\section{References}

[1] Cosimato, S. and Troisi, O., 2015. Green supply chain management: Practices and tools for logistics competitiveness and sustainability. The DHL case study. The TQM Journal, 27(2), pp.256-276.

[2] Geroliminis, N. and Daganzo, C.F., 2008. Existence of urban-scale macroscopic fundamental diagrams: Some experimental findings. Transportation Research Part B: Methodological, 42(9), pp.759-770.

[3] Geroliminis, N. and Daganzo, C.F., 2008. Existence of urban-scale macroscopic fundamental diagrams: Some experimental findings. Transportation Research Part B: Methodological, 42(9), pp.759-770..

[4] Hans, I.W., 2011. Green Supply Chains - a new priority for supply chain managers CSIR Built Environment. [referenced 5 January, 2013]

[5] Lee, S.Y. and Klassen, R.D., 2008. Drivers and enablers that foster environmental management capabilities in small-and medium-sized suppliers in supply chains. Production and Operations management, 17(6), pp.573-586.

[6] Lyon, T.P. and Maxwell, J.W., 2008. Corporate social responsibility and the environment: $A$ theoretical perspective. Review of environmental economics and policy, 2(2), pp.240-260.

[7] Mesjasz-Lech, A., 2011. Efektywność ekonomiczna i sprawność ekologiczna logistyki zwrotnej, (pp. 43-46). Czestochowa: Published by Technical University of Czestochowa.

[8] Nowakowska-Grunt, J., 2008. Impact of Lean management on logistics infrastructure in enterprises. Advanced Logistic systems, 2(1), pp.71-74.

[9] Pesch, M.J., Murphy, R.T. and Ahmad, S., 2012. Murphy Warehouse Company. Journal of the International Academy for Case Studies, 18(3), p.125.

[10]Rodrigue, J.P., Slack, B. and Comtois, C., 2012. Green logistics. In Handbook of logistics and supply-chain management (pp. 339-350). Emerald Group Publishing Limited.

[11]Sbihi, A. and Eglese, R.W., 2009. Combinatorial optimization and green logistics. Annals of Operations Research, 175(1), pp.159-175. 